\title{
Analisis Quality of Services Jaringan VoIP pada VPN menggunakan InterAsteriks Exchange dan Session Initiation Protocol
}

Quality of Services Analysis of VoIP Networks over VPN using InterAsteriks Exchange and Session Initiation Protocol

Agus Heriyanto $^{1}$, Lailis Syafaah ${ }^{2}$, Amrul Faruq $^{3}$

1,2,3Jurusan Teknik Elektro, Fakultas Teknik, Universitas Muhammadiyah Malang

E-mail: faruq@umm.ac.id

\begin{abstract}
Abstrak
Di dalam komunikasi Voice over Internet Protocol (VoIP) mengenal beberapa macam protocol tambahan selain protocol standar internet Transfer Control Protocol/Internet Protocol $(T C P / I P)$, beberapa diantaranya adalah protocol Session Initation Protocol (SIP), Inter-Asterisk eXchange (IAX) dan H.323. Performansi perlu dijaga mengingat VoIP mempunyai kemungkinan melakukan berbagai cara kompresi untuk menciptakan efisiensi saluran dan pemilihan protocol yang tepat. Teknologi VoIP pada dasarnya tidak memiliki jaminan keamanan pada setiap komunikasi. Keamanan ketika melakukan komunikasi suara merupakan sesuatu yang sangat penting karena menyangkut privasi penggunanya. Penggunaan Virtual Private Network (VPN) merupakan salah satu solusi untuk menutup celah keamanan pada kasus di atas. Analisis yang dilakukan pada artikel ini adalah performa yang dihasilkan VoIP yang menggunakan protocol $I A X$ dan SIP. Penelitian ini mengahasilkan kesimpulan bahwa performansi yang paling baik digunakan untuk membangun sistem komunikasi VoIP adalah protocol IAX dengan menggunakan sistem keamanan VPN Point to Point Protocol (PPTP) dikarenakan nilai Quality of Service $(Q o S)$ lebih tinggi daripada protocol SIP dan juga terbukti lebih aman saat diterapkan sistem keamanan Virtual Private Network Point to Point Protocol (VPN PPTP).
\end{abstract}

Kata kunci: Voice over Internet Protocol, Quality of Services, Virtual Private Network, SIP, IAX

\begin{abstract}
In VoIP communication, there are several additional protocols beside the standard TCP/IP protocols, some of them are the Session Initation Protocol (SIP), Inter-Asterisk eXchange (IAX), and H.323. Performance needs to be maintained given that VoIP has the possibility to perform various compression methods to create channel efficiency and selection of the right protocol. VoIP technology basically does not have a guarantee of security on every communication. Security when conducting voice communication is something that is very important due to it involves the privacy of its users. The use of a Virtual Private Network (VPN) is one solution to close the security gap in the case mentioned. The analysis carried out in this article is the performance produced by VoIP using the IAX and SIP protocols. In this study concluded that the best performance used to build a VoIP communication system is the IAX Protocol using a Point to Point Protocol (PPTP) security system because the Quality of Service $(Q o S)$ value is higher than the SIP protocol and also proved to be safer when applied PPTP VPN security system.
\end{abstract}

Keywords: Voice over Internet Protocol, Quality of Services, Virtual Private Network, SIP, IAX 


\section{PENDAHULUAN}

Dewasa ini perkembangan teknologi yang sangat pesat mendorong terbentuknya suatu komunikasi yang bersifat convergence dengan teknologi komunikasi lainnya. Salah satunya adalah Voice over Internet Protocol (VoIP). VoIP merupakan teknologi yang menawarkan layanan transmisi data suara, video, dan data secara langsung atau real time melalui internet yang berjalan pada suatu protocol jaringan komputer yaitu Internet Protocol (IP). Teknologi VoIP merupakan teknologi yang dapat mengkonversi suara menjadi signal digital dan kemudian ditransmisikan menjadi paket-paket data yang bekerja pada protocol IP [1]. Penggunaan jaringan IP memungkinkan penghematan biaya, karena tidak perlu membangun sebuah infrastruktur baru untuk komunikasi suara dan penggunaan bandwith yang lebih kecil dibandingkan telepon biasa. Teknologi ini (VoIP) dapat dikembangkan sedemikian rupa sesuai dengan keinginan dan biaya penggunaan yang murah serta banyak keuntungan yang dapat diambil [2].

Dalam pengoperasiannya, VoIP memiliki protocol yang merupakan sebuah aturan yang harus dipenuhi agar akses komunikasi dalam hal ini komunikasi VoIP dapat melewati jaringan. Di dalam komunikasi VoIP mengenal beberapa macam protocol tambahan selain protocol standar internet TCP/IP, beberapa diantaranya adalah protocol SIP, IAX dan H.323. Session Initiation Protocol (SIP) adalah protocol yang dikembangkan oleh Internet Engineering Task Force (IETF), kemudian IAX atau singkatan dari Inter Asterisk eXchange adalah protocol yang dibuat dan dikembangkan oleh komunitas Asterisk, sedangkan H.323 adalah protocol yang di rekomendasikan oleh ITU Telecommunication Standardization Sector (ITU-T) [3].

Pada penelitian sebelumnya dapat kita ketahui hasil dari performansi VoIP yang menggunakan protocol SIP seperti pada hasil pengujian kualitas suara pada VoIP Computer to Computer Berbasis Freeware Menggunakan Session Initiation Protocol [4] dan pada pekerjaan yang lain implementasi VoIP SIP Pada Mobile Phone di Jaringan Bluetooth [5]. Secara umum sistem VoIP yang menggunakan protocol SIP dapat beroperasi dengan baik serta memiliki kualitas suara yang cukup memuaskan. Dikarenakan Protocol VoIP tidak hanya SIP saja, maka dari itu pekerjaan ini mengeksplorasi protocol-protocol lainnya pada VoIP agar dapat dijadikan pengambilan keputusan untuk menentukan protocol mana yang terbaik pada perancangan sistem VoIP yang dibangun [6]. Lebih jauh lagi, penelitian [7] menyajikan simulasi jaringan SIP real time dan sistem pemantauan (monitoring). Simulator jaringan SIP didasarkan pada model generatif probabilistik yang meniru jaringan sosial pelanggan VoIP yang saling memanggil secara acak. Sistem pemantauan, dipasang di server SIP, menyediakan layanan untuk mengumpulkan data jaringan dan statistik server secara real time. Sistem ini menyediakan kerangka kerja yang kuat untuk mengembangkan aplikasi jaringan SIP seperti monitor keamanan.

Performansi perlu dijaga mengingat VoIP mempunyai kemungkinan melakukan berbagai cara kompresi untuk menciptakan efisiensi saluran dan pemilihan protocol yang tepat. Belum lagi dengan jaminan keamanan terhadap setiap paket data pada setiap komunikasi suara yang dilakukan. Teknologi VoIP pada dasarnya tidak memiliki jaminan keamanan pada setiap komunikasi. Karena penggunaan komunikasi yang murah dari sisi keamanan kurang begitu diperhatikan. Hal ini disebabkan karena media transmisi paket data yang melalui unprotected network pada jaringan internet. Sehingga memungkinkan penyadapan atau peretasan komunikasi suara maupun data-data oleh pihak yang tidak bertanggungjawab. Salah satu kelemahan jaringan internet adalah bahwa data yang terkirim tidak terjamin kerahasiaannya sehingga siapapun dapat mengambildan memanipulasi data tersebut [1].

Setiap komunikasi antar user yang melalui jaringan internet dapat dilakukan penyadapan, sehingga percakapan antar user dapat diretas atau disadap. Hal ini ditakutkan jika ada pihak yang tidak bertanggung jawab mencuri informasi yang beredar. Tentunya hal ini dapat menjadi kerugian bagi user tersebut [8]. Pada referensi [9], implementasi keamanan jaringan komunikasi VoIP berbasis protocol SIP berhasil dilakukan. Artikel tersebut menyajikan hasil arsitektur konkret dan layak untuk mengamankan panggilan VoIP. Sementara itu, 
kaitannya dengan keamanan jaringan, VoIP pada jaringan Internet Protocol versi 6 (IPv6) juga sudah dianalisa dengan system tunnelling [10].

Oleh karena itu, keamanan ketika melakukan komunikasi suara merupakan sesuatu yang sangat penting karena menyangkut privasi penggunanya pada arsitektur VoIP. Penggunaan Virtual Private Network $(V P N)$ merupakan salah satu solusi untuk menutup celah keamanan pada kasus di atas. VPN merupakan salah satu alternatif untuk mengirimkan data dan suara, yang bersifat private atau aman [11]. Menyatukan VoIP dengan Internet of Things (IoT) teknologi merupakan skema baru yang dapat dijadikan alternatif keamanan jaringan VoIP terhadap potensi ancaman [12]. Pada artikel ini bertujuan untuk investigasi performa yang dihasilkan VoIP yang menggunakan protocol SIP dan IAX sekaligus mengevaluasi penggunaan keduanya dengan mengukur tingkat Quality of Services. Kemudian dilakukan analisis pada performa VoIP tanpa VPN dengan VoIP yang menerapkan VPN pada saat jaringan sibuk dan atau pada saat jaringan lenggang. Selain itu juga perlu dipertimbangkan terkirimnya data secara real-time agar tercapainya Quality of Service (QoS) pada jaringan VoIP yang digunakan.

\section{METODE PENELITIAN}

Pekerjaan ini menggunakan pendekatan penelitian eksperimental. Penelitian eksperimental adalah penelitian yang dilakukan dengan menciptakan fenomena pada kondisi terkendali. Penelitian ini bertujuan untuk menemukan perbandingan dan pengaruh faktor-faktor pada kondisi tertentu. Penelitian ini berupaya menjelaskan perbandingan antara dua protocol berbeda pada sebuah sistem telekomunikasi yang sama yaitu Voice over Internet Protocol (VoIP) dari segi performansi dan keamanan sebuah protocol yang diterapkan. Protocol yang dianalisa adalah protocol IAX dan protocol SIP dengan tambahan sistem keamanan VPN pada masing-masing implementasinya.

\subsection{Diagram Alir Perancangan Sistem}

Untuk melakukan penelitian pada Analisis Performansi dan Keamanan Voice over Internet Protocol (VoIP) Pada Jaringan Virtual Private Network (VPN) Berbasis Protocol InterAsterisk eXchange (IAX), dapat dilakukan dengan beberapa langkah seperti terlihat dalam gambar 1. Blok diagram penelitian seperti dilihatkan pada Gambar 2. Sedangkan topologi jaringan VoIP yang dibangun pada pekerjaan ini dapat dilihat pada Gambar 3.

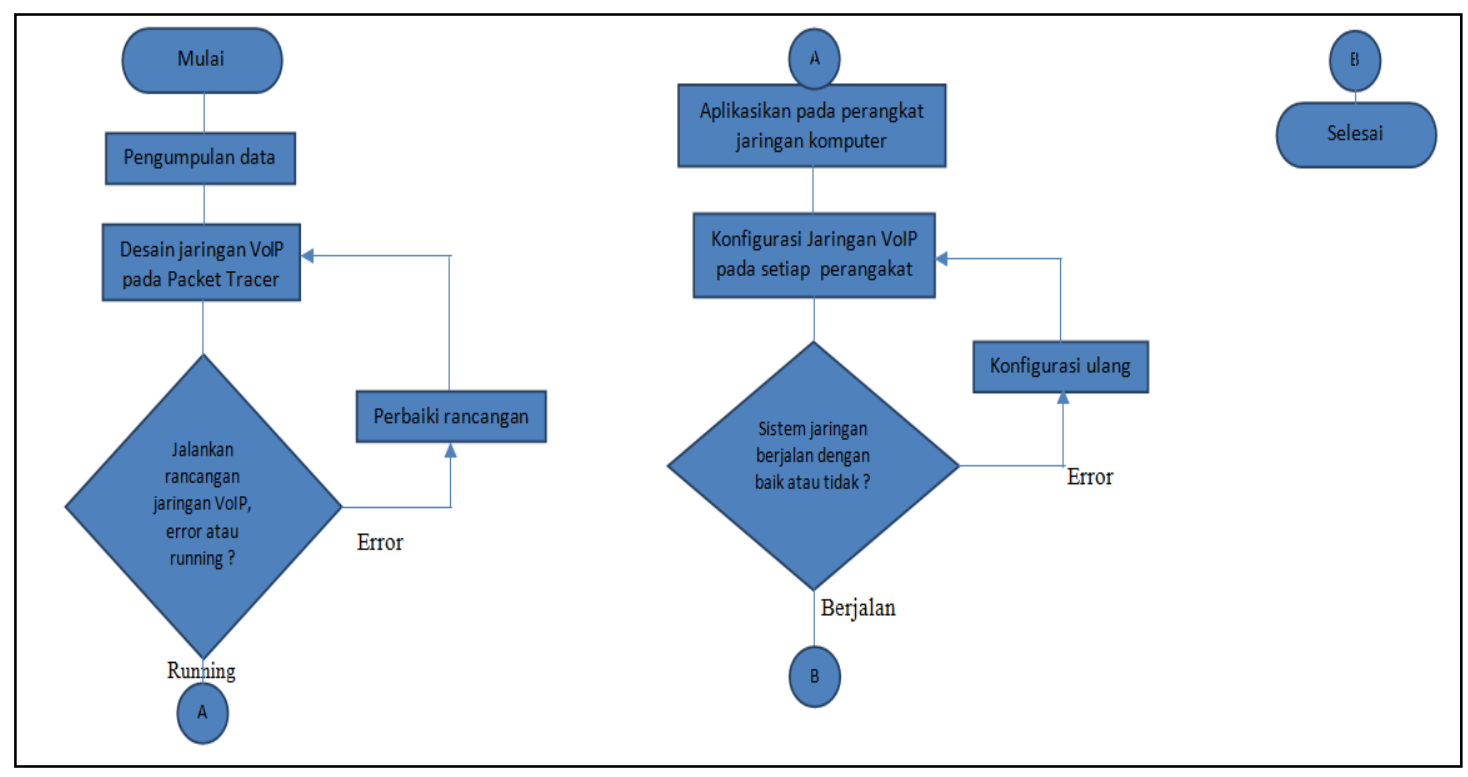

Gambar 1 Diagram Alir Perencanaan Jaringan VoIP 


\subsection{Cara Kerja dan Pengujian}

a. Instalasi sistem operasi pada server VoIP

Instalasi sistem operasi VoIP server pada penelitian ini dengan menggunakan Open Source Linux Free PBX. Alasan penulis menggunakan sistem operasi FreePBX karena sistem operasi ini mudah dikonfigurasi dikarenakan sudah mendukung Graphical User Interface (GUI) dan dapat menggunakan multi protocol tanpa harus menginstal ulang atau mengkonfigurasi kembali ketika ingin berpindah atau berganti protocol yang akan diterapkan [13].

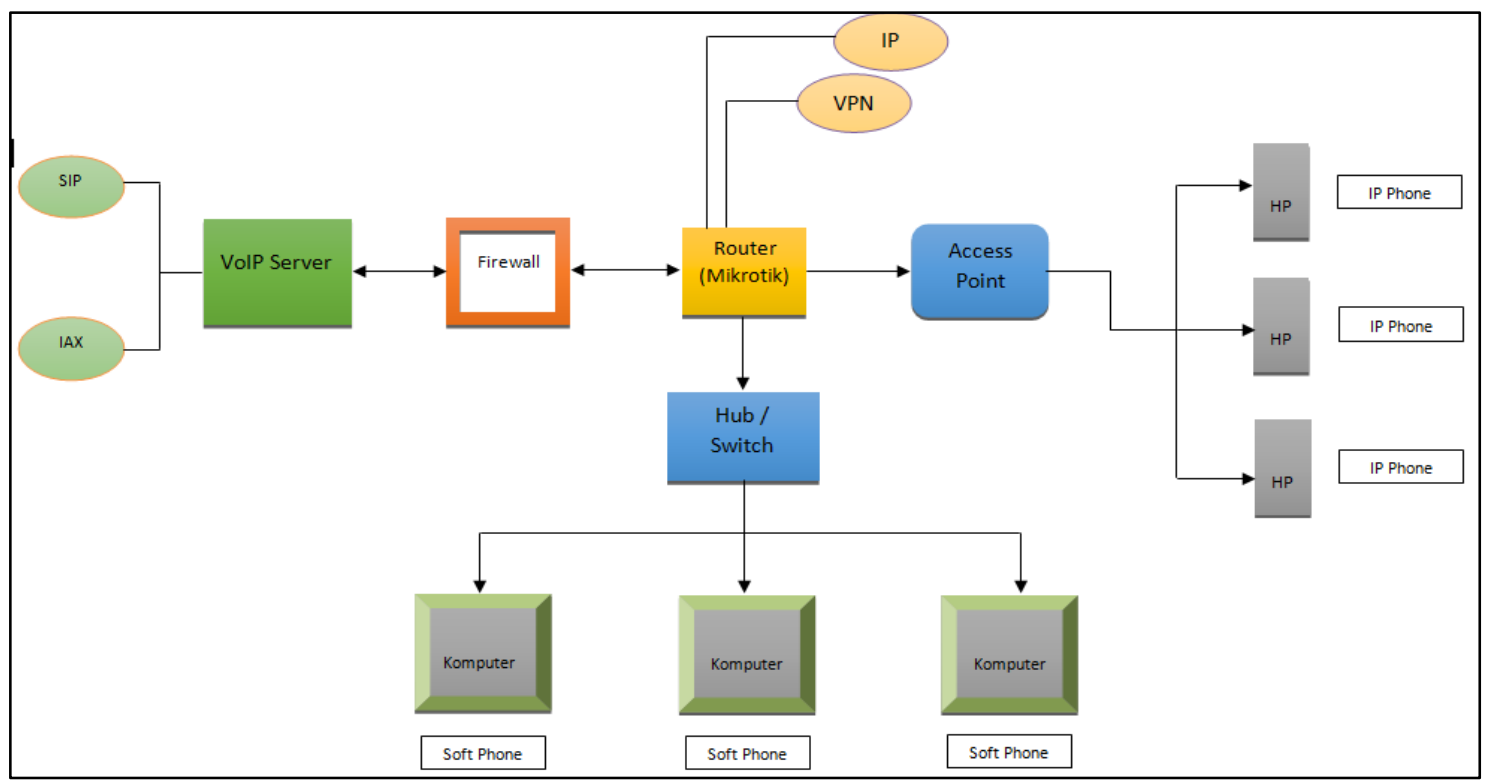

Gambar 2 Blok Diagram Sistem VoIP

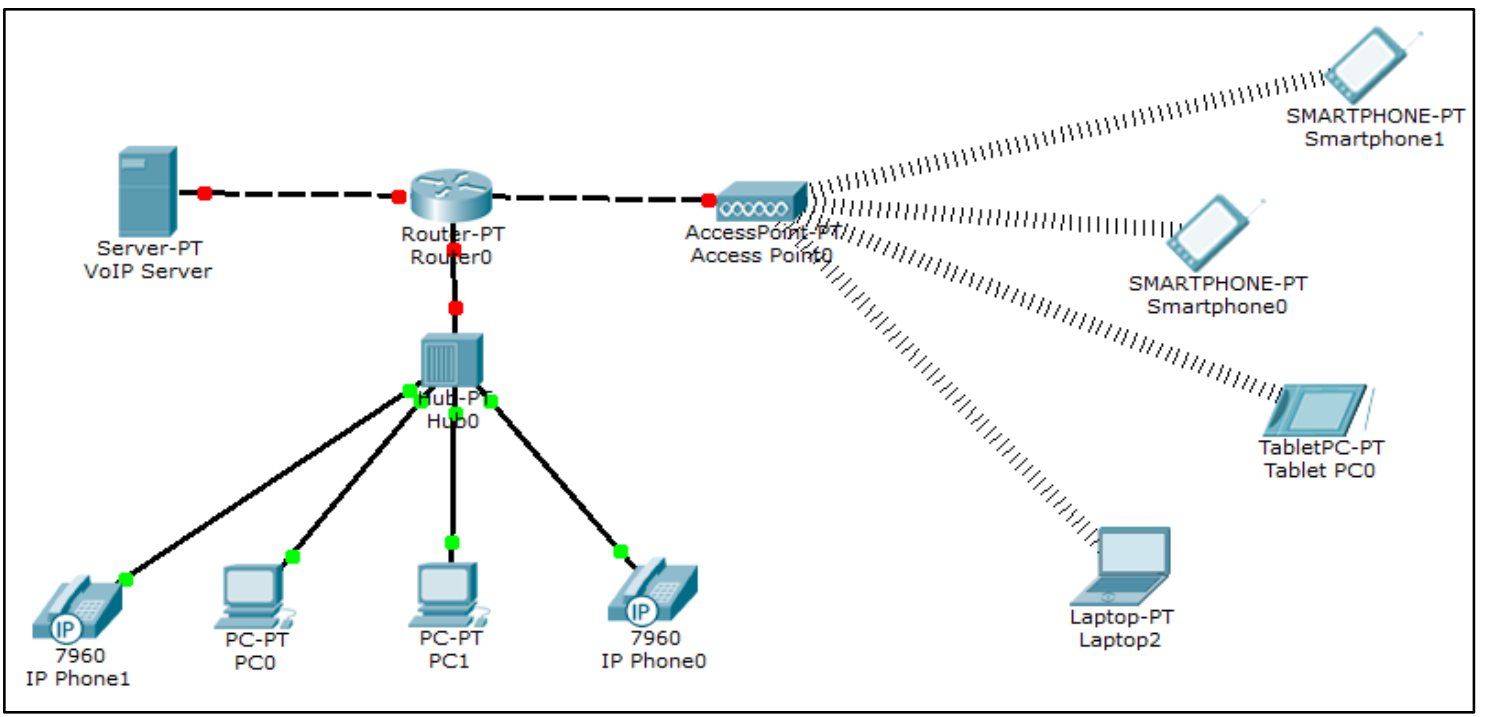

Gambar 3 Emulasi Topologi Jaringan VoIP

b. Konfigurasi server VoIP

Konfigurasi pada VoIP server ada 3 yaitu berturut-turut meliputi konfigurasi protocol standar, konfigurasi protocol VoIP, dan konfigurasi user pada VoIP server.

c. Konfigurasi pada router Mikrotik

Pada perangkat router dibutuhkan konfigurasi untuk mengatur lalu-lintas jaringan 
antara server dan user. Konfigurasi pada router adalah sebagai berikut meliputi Ethernet, Internet Protocol (IP), konfigurasi Dynamic Host Configuration Protocol (DHCP) server, VPN point to point protocol (PPTP) [14].

d. Konfigurasi pada Access Point IP Service Set Identifier (SSID) Password Wi-Fi DHCP Server

e. Konfigurasi pada user

Konfigurasi pada perangkat yang digunakan user terbagi dua yaitu pada perangkat komputer/laptop instalasi dan konfigurasi softphone Zoiper, dan konfigurasi VPN client dan pada perangkat smartphone meliputi instalasi dan konfigurasi softphone Zoiper

\section{HASIL DAN PEMBAHASAN}

Dalam pembuatan sistem jaringan VoIP untuk menganalisa performansi dan keamanannya dilakukan prosedur operasi dan pengujian yang mengacu pada desain perancangan hal ini dijelaskan dengan beberapa tahap yang harus dilakukan seperti yang telah diterangkan pada bagian sebelumnya. Uji paramater-parameter yang mempengaruhi performansi Quality of Services $(Q o S)$ pada jaringan IP yang dibatasi pada masalah seperti ditunjukkan dalam persamaan (1) sampai dengan persamaan (4), yang masing-masing adalah Throughput, Jitter, Packet loss dan Delay.

$$
\begin{aligned}
& \text { Throughput }=\frac{\text { Paket Data Yang Diterima }}{\text { Lama Pengamatan }} \\
& \text { Jitter }=\frac{\text { Total Variasi Delay }}{\text { Paket Yang Diterima }} \\
& \text { P. Loss }=\frac{\text { Paket Data Terkirim }- \text { Paket Data Diterima }}{\text { Paket Data Terkirim }} \times 100 \% \\
& \text { Delay Rata }- \text { Rata }=\frac{\text { Lama Pengamatan }}{\text { Total Paket Yang Diterima }} \ldots
\end{aligned}
$$

Hasil uji performansi VoIP dengan protocol IAX tanpa menggunakan keamanan VPN PPTP dapat dilihat pada Tabel 1. Dari hasil uji menjelaskan hasil dari delay adalah $9.276 \mathrm{ms,}$ kemudian data kedua yaitu jitter yang bernilai $5.841 \mathrm{~ms}$, data ketiga adalah throughput yang bernilai $50 \%$ dan data keempat adalah packet loss yang bernilai $0 \%$.

Tabel 1 Hasil uji performansi IAX tanpa VPN

\begin{tabular}{|c|c|}
\hline Parameter & Nilai \\
\hline Delay & 9.276 \\
\hline Jitter & 5.841 \\
\hline Throughput & $50 \%$ \\
\hline Packet loss & $0 \%$ \\
\hline
\end{tabular}

Hasil uji performansi VoIP dengan protocol IAX yang menggunakan keamanan VPN PPTP dapat dilihat pada Tabel 2. Pada data hasil tersebut menjelaskan hasil dari delay adalah $9.580 \mathrm{~ms}$, kemudian data kedua yaitu jitter yang bernilai $8.284 \mathrm{~ms}$, data ketiga adalah throughput yang bernilai 54\% dan data keempat adalah packet loss yang bernilai $6.17 \%$. 
Tabel 2 Hasil uji performansi IAX dengan VPN

\begin{tabular}{|c|c|}
\hline Parameter & Nilai \\
\hline Delay & 9.580 \\
\hline Jitter & 8.284 \\
\hline Throughput & $54 \%$ \\
\hline Packet loss & $6.17 \%$ \\
\hline
\end{tabular}

Hasil uji performansi VoIP dengan protocol SIP tanpa menggunakan keamanan VPN PPTP dapat dilihat pada Tabel 3. Tabel 3. menjelaskan hasil dari delay adalah $9.706 \mathrm{~ms}$, kemudian data kedua yaitu jitter yang bernilai $5.541 \mathrm{~ms}$, data ketiga adalah throughput yang bernilai $52 \%$ dan data keempat adalah packet loss yang bernilai $6.17 \%$.

Tabel 3 Hasil uji performansi SIP tanpa VPN

\begin{tabular}{|c|c|}
\hline Parameter & Nilai \\
\hline Delay & 9.706 \\
\hline Jitter & 5.541 \\
\hline Throughput & $52 \%$ \\
\hline Packet loss & $6.17 \%$ \\
\hline
\end{tabular}

Hasil uji performansi VoIP dengan protocol SIP dengan menggunakan keamanan VPN PPTP dapat dilihat pada Tabel 4. Tabel 4. menjelaskan hasil dari delay adalah $9.6553 \mathrm{~ms}$, kemudian data kedua yaitu jitter yang bernilai $5.101 \mathrm{~ms}$, data ketiga adalah throughput yang bernilai $54 \%$ dan data keempat adalah packet loss yang bernilai $6 \%$.

Tabel 4 Hasil uji performansi SIP tanpa VPN

\begin{tabular}{|c|c|}
\hline Parameter & Nilai \\
\hline Delay & 9.6553 \\
\hline Jitter & 5.101 \\
\hline Throughput & $54 \%$ \\
\hline Packet loss & $6 \%$ \\
\hline
\end{tabular}

Hasil perbandingan indeks delay dapat dilihat pada Tabel 5. Pengukuran Delay pada $I A X$ tanpa VPN, IAX dengan VPN, SIP tanpa VPN dan SIP dengan VPN berdasarkan nilai Delay sesuai dengan versi TIPHON sebagai standarisasi, untuk kategori Delay sangat bagus jika $<150$ ms, bagus jika $150 \mathrm{~ms} s / \mathrm{d} 300 \mathrm{~ms}$, sedang jika $300 \mathrm{~ms} s / \mathrm{d} 450 \mathrm{~ms}$, dan jelek jika > $450 \mathrm{~ms}$ maka didapat Rata - Rata Indeks Delay di Tabel 5 untuk setiap protocol adalah "Sangat Bagus" dengan Nilai Indeks "4" dan yang paling kecil delaynya adalah protocol IAX tanpa menggunakan keamanan VPN PPTP.

Tabel 5 Hasil perbandingan indeks delay

\begin{tabular}{|c|c|c|c|}
\hline \multirow{2}{*}{ Protocol \& Keamanan } & \multirow{2}{*}{ Rata-Rata Delay } & \multicolumn{2}{|c|}{ Rata-Rata } \\
\cline { 3 - 4 } & & Indeks & Kategori \\
\hline$I A X$ tanpa $V P N$ & 9.276 & 4 & Sangat bagus \\
\hline$I A X$ dengan $V P N$ & 9.580 & 4 & Sangat bagus \\
\hline$S I P$ tanpa $V P N$ & 9.706 & 4 & Sangat bagus \\
\hline$S I P$ dengan $V P N$ & 9.655 & 4 & Sangat bagus \\
\hline
\end{tabular}

Hasil perbandingan indeks jitter dapat dilihat pada Tabel 6. Pengukuran Jitter pada IAX tanpa VPN, IAX dengan VPN, SIP tanpa VPN dan SIP dengan VPN berdasarkan nilai Jitter sesuai dengan versi TIPHON sebagai standarisasi, untuk kategori Jitter "Sangat Bagus jika 0 ms, "Bagus" jika 0 ms s/d 75 ms, "Sedang" jika 75 ms s/d 125 ms, dan "Jelek" jika $125 \mathrm{~ms} \mathrm{~s} / \mathrm{d}$ 225 ms maka didapat hasil rata-rata indeks Jitter di Tabel 6 untuk setiap protocol dan keamanan adalah "Bagus" dengan Nilai Indeks "3" dan yang paling rendah jitternya adalah protocol SIP dengan menggunakan keamanan VPN PPTP. 
Tabel 6 Hasil perbandingan indeks jitter

\begin{tabular}{|c|c|c|c|}
\hline \multirow{2}{*}{ Protocol \& Keamanan } & \multirow{2}{*}{ Rata-Rata Jitter } & \multicolumn{2}{|c|}{ Rata-Rata } \\
\cline { 3 - 4 } & & Indeks & Kategori \\
\hline$I A X$ tanpa $V P N$ & 5.841 & 3 & Bagus \\
\hline$I A X$ dengan $V P N$ & 8.284 & 3 & Bagus \\
\hline$S I P$ tanpa $V P N$ & 5.541 & 3 & Bagus \\
\hline$S I P$ dengan $V P N$ & 5.101 & 3 & Bagus \\
\hline
\end{tabular}

Hasil perbandingan indeks throughput dapat dilihat pada Tabel 7. Pengukuran Throughput pada IAX tanpa VPN, IAX dengan VPN, SIP tanpa VPN dan SIP dengan VPN berdasarkan nilai Throughput sesuai dengan versi TIPHON sebagai standarisasi, untuk kategori Throughput sangat bagus jika persentase Throughput $100 \%$, bagus jika persentase Throughput $75 \%$, sedang jika persentase Throughput $50 \%$, dan jelek jika persentase Throughput $>25 \%$ maka didapat Rata - Rata Indeks Throughput di Tabel 7 untuk setiap protocol dan keamanan adalah "Sedang" dengan Nilai Indeks " 2 " dan yang paling tinggi nilai throughputya adalah protocol IAX dan SIP dengan menggunakan keamanan VPN PPTP.

Hasil perbandingan indeks packet loss dapat dilihat pada Tabel 8. Pengukuran Packet loss pada IAX tanpa VPN, IAX dengan VPN, SIP tanpa VPN dan SIP dengan VPN berdasarkan nilai Packet loss sesuai dengan versi TIPHON sebagai standarisasi, untuk kategori Packet loss "SangatBagus" jika 0 \%, "Bagus" jika $3 \%$, "Sedang" jika $15 \%$, dan "Jelek" jika $25 \%$ maka didapat Rata - Rata Indeks Packet loss di Tabel 8 untuk setiap protocol dan keamanan adalah "Bagus" dengan Nilai Indeks "3" dan yang paling rendah packet lossnya adalah protocol IAX tanpa $V P N$.

Tabel 7 Hasil perbandingan indeks throughput

\begin{tabular}{|c|c|c|c|}
\hline \multirow{2}{*}{ Protocol \& Keamanan } & \multirow{2}{*}{ Rata-Rata Throughput } & \multicolumn{2}{|c|}{ Rata-Rata } \\
\cline { 3 - 4 } & & Indeks & Kategori \\
\hline$I A X$ tanpa $V P N$ & $50 \%$ & 2 & Sedang \\
\hline$I A X$ dengan $V P N$ & $54 \%$ & 2 & Sedang \\
\hline$S I P$ tanpa $V P N$ & $52 \%$ & 2 & Sedang \\
\hline$S I P$ dengan $V P N$ & $54 \%$ & 2 & Sedang \\
\hline
\end{tabular}

Tabel 8 Hasil perbandingan indeks packet loss

\begin{tabular}{|c|c|c|c|}
\hline \multirow{2}{*}{ Protocol \& Keamanan } & \multirow{2}{*}{$\begin{array}{c}\text { Rata-Rata } \\
\text { Packet loss }\end{array}$} & \multirow{2}{*|}{ Rata-Rata } \\
\cline { 3 - 4 } & Indeks & Kategori \\
\hline$I A X$ tanpa $V P N$ & $0 \%$ & 4 & Sangat Bagus \\
\hline$I A X$ dengan $V P N$ & $6.17 \%$ & 3 & Bagus \\
\hline$S I P$ tanpa $V P N$ & $6.17 \%$ & 3 & Bagus \\
\hline$S I P$ dengan $V P N$ & $6 \%$ & 3 & Bagus \\
\hline
\end{tabular}

Hasil perbandingan Nilai QoS VoIP pada tiap protocol dapat dilihat pada Tabel 9. Pengukuran nilai QoS pada tiap protocol dengan atau tanpa menggunakan sistem keamanan $V P N$ dapat dilihat dari Tabel 9 yaitu hasil akhirnya adalah protocol IAX tanpa VPN, IAX dengan $V P N$ dan SIP dengan VPN adalah memuaskan sedangkan protocol SIP tanpa VPN hasilnya kurang memuaskan. Tetapi yang paling tinggi nilainya adalah protocol IAX tanpa menggunakan sistem keamanan $V P N$ yaitu dengan nilai total rata-rata 3.25.

Tabel 9 Hasil perbandingan nilai QoS

\begin{tabular}{|c|c|c|c|c|c|c|}
\hline Protocol & $\begin{array}{c}\text { Nilai } \\
\text { Indeks } \\
\text { Delay }\end{array}$ & $\begin{array}{c}\text { Nilai } \\
\text { Indeks } \\
\text { Jitter }\end{array}$ & $\begin{array}{c}\text { Nilai } \\
\text { Indeks } \\
\text { Throughput }\end{array}$ & $\begin{array}{c}\text { Nilai } \\
\text { Indeks } \\
\text { Packet loss }\end{array}$ & $\begin{array}{l}\text { Jumlah Rata- } \\
\text { Rata Nilai }\end{array}$ & Keterangan Nilai \\
\hline$I A X$ tanpa $V P N$ & 4 & 3 & 2 & 4 & 3.25 & Memuaskan \\
\hline$I A X$ dengan $V P N$ & 4 & 3 & 2 & 3 & 3 & Memuaskan \\
\hline$S I P$ tanpa $V P N$ & 4 & 3 & 2 & 2 & 2.75 & Kurang Memuaskan \\
\hline
\end{tabular}


Gambar 4 menjelaskan uji keamanan pada protocol IAX tanpa menggunakan keamanan VPN PPTP adalah percakapan dari dua client dapat disadap menggunakan software Wireshark dan hasil sadapan bisa disimpan dan diputar kembali menggunakan player yang berarti komunikasi dengan menggunakan protocol IAX tanpa mengguanakan keamanan VPN PPTP tidak aman dan mempunyai celah untuk penyadapan dari pihak yang tidak bertanggung jawab.

Hasil uji keamanan VoIP dengan protocol IAX dengan menggunakan keamanan VPN PPTP dapat dilihat pada Gambar 5. Pada gambar 5 menjelaskan uji keamanan pada protocol $I A X$ dengan menggunakan keamanan VPN PPTP adalah percakapan dari dua client tidak dapat disadap menggunakan software Cain and Able karena pada penelitian ini dihasilkan keterangan bahwa hasil sadapan tidak bisa diputar menggunakan player ataupun disimpan dikarenakan paket data percakapan dienkripsi oleh VPN PPTP sehingga codec untuk file sadapan tidak bisa dibaca oleh player manapun yang berarti komunikasi dengan menggunakan protocol IAX dengan mengguanakan keamanan VPN PPTP aman dan tidak mempunyai celah untuk penyadapan dari pihak yang tidak bertanggung jawab.

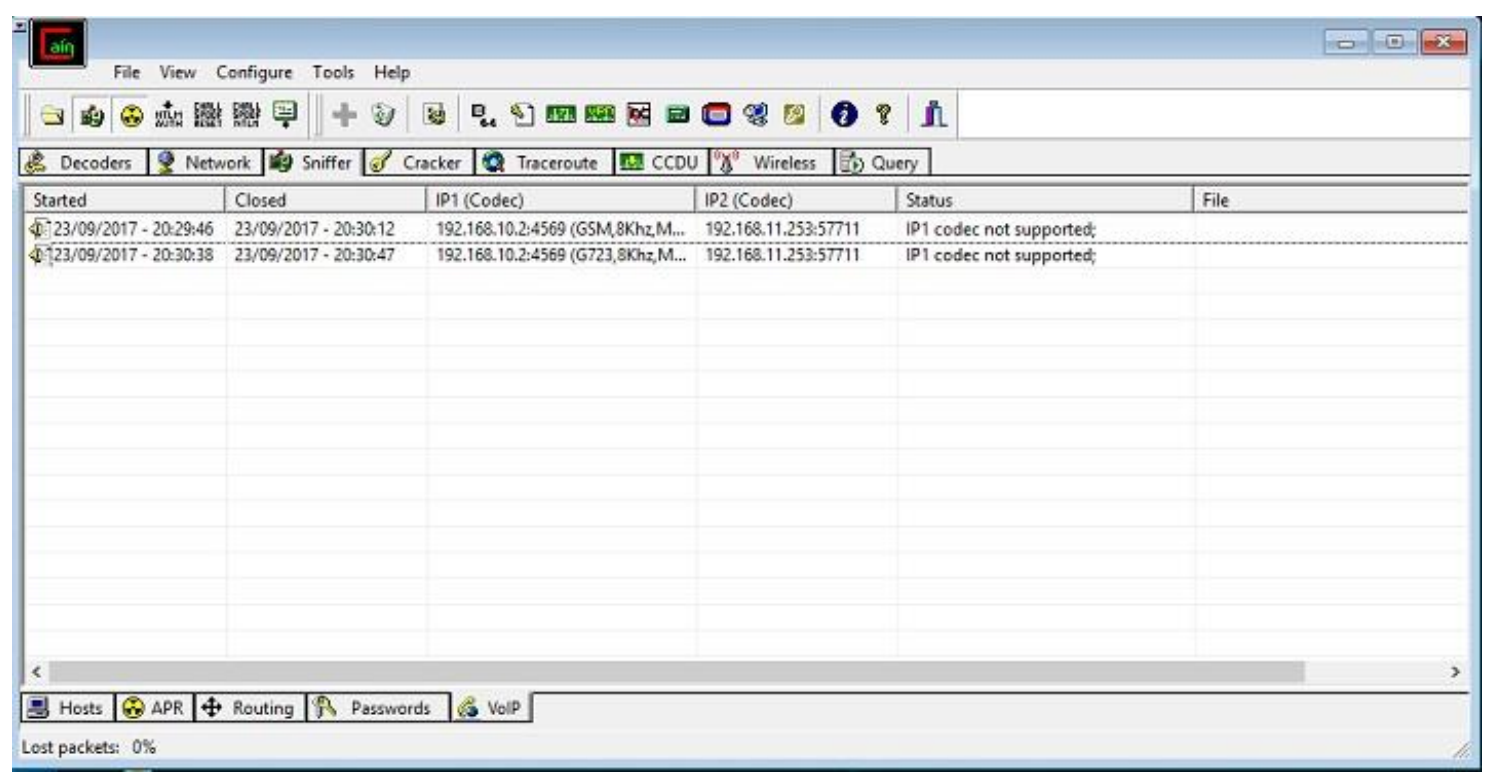

Gambar 4 Hasil uji keamanan VoIP IAX dengan VPN menggunakan Cain and Able

Pada gambar 5 menjelaskan uji keamanan pada protocol SIP tanpa menggunakan keamanan VPN PPTP adalah percakapan dari dua client dapat disadap menggunakan software Cain and Able dan hasil sadapan bisa disimpan dan diputar kembali menggunakan player yang berarti komunikasi dengan menggunakan protocol SIP tanpa mengguanakan keamanan VPN PPTP tidak aman dan mempunyai celah untuk penyadapan dari pihak yang tidak bertanggung jawab. Pada gambar 6 menjelaskan uji keamanan pada protocol SIP dengan menggunakan keamanan VPN PPTP adalah percakapan dari dua client tidak dapat disadap menggunakan software Cain and Able karena pada penelitian ini dihasilkan keterangan bahwa hasil sadapan tidak bisa diputar menggunakan player ataupun disimpan dikarenakan paket data percakapan dienkripsi oleh VPN PPTP sehingga codec untuk file sadapan tidak bisa dibaca oleh player manapun yang berarti komunikasi dengan menggunakan protocol SIP dengan mengguanakan keamanan VPN PPTP aman dan tidak mempunyai celah untuk penyadapan dari pihak yang tidak bertanggung jawab. 


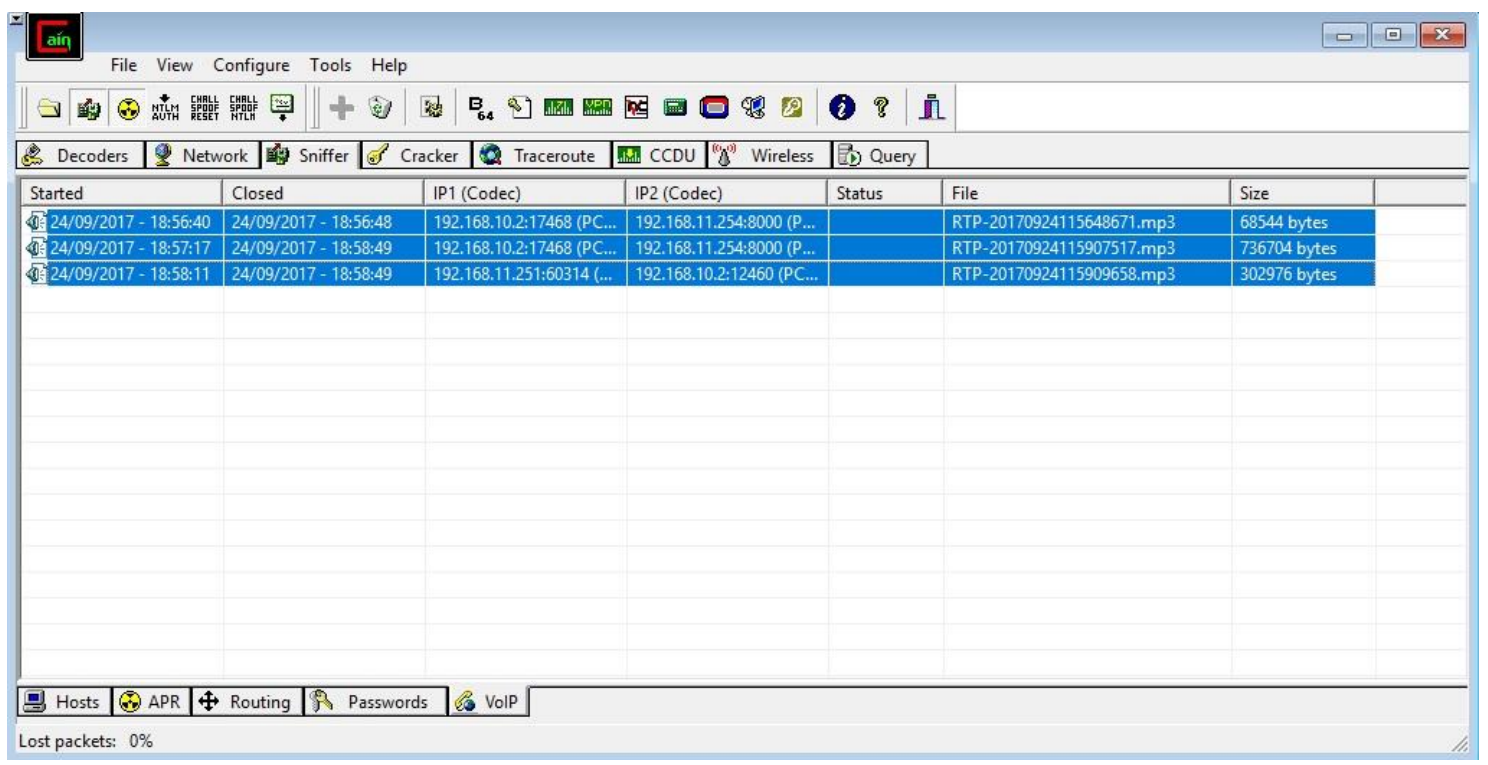

Gambar 5 Hasil uji keamanan VoIP SIP tanpa VPN menggunakan Cain and Able

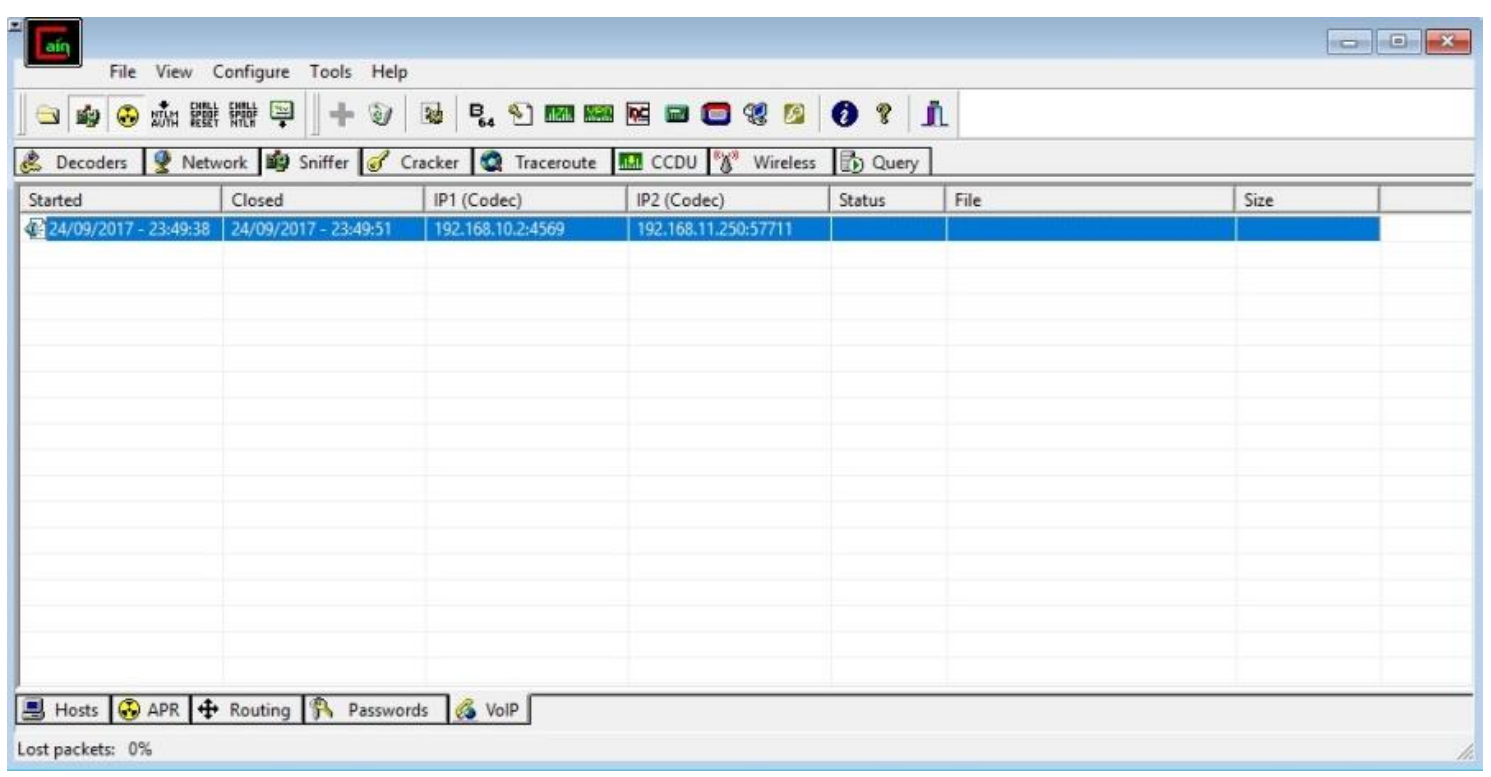

Gambar 6 Hasil uji keamanan VoIP SIP dengan VPN menggunakan Cain and Able

\section{KESIMPULAN DAN SARAN}

Pada uji performansi delay, jitter, throughput dan packet loss pada tiap protocol VoIP dengan atau tanpa menggunakan sistem keamanan $V P N$ yang paling tinggi nilainya adalah protocol IAX tanpa menggunakan sistem keamanan VPN yaitu dengan nilai rata-rata 3.25 mendekati predikat sangat memuaskan. Pada uji tingkat keamanan tiap protocol VoIP dengan atau tanpa menggunakan sistem keamanan VPN dapat dilihat hasilnya tiap protocol yang menggunakan sistem keamanan VPN lebih aman daripada protocol VoIP yang tidak menggunakan sistem keamanan $V P N$ dikarenakan protocol yang menggunakan VPN tidak terbaca pada saat penyadapan dilakukan pada software sniffing atau penyadap dikarenakan paket data yang dikirim maupun yang diterima antar client dienkripsi oleh sistem VPN PPTP 
pada server VPN router.

Pada kasus pekerjaan ini, dapat disimpulkan protocol yang sesuai digunakan untuk membangun sistem komunikasi VoIP adalah "Protocol IAX" dikarenakan nilai QoSnya lebih tinggi daripada protocol SIP dan juga terbukti saat diterapkan sistem keamanan VPN software penyadap tidak dapat membaca paket data percakapan dikarenakan telah dienkripsi oleh sistem VPN PPTP.

Penelitian selanjutnya bisa ditujukan pada pengembangan jaringan VoIP terintegrasi pada teknologi Internet of Things, seperti diketahui bahwa koenktifitas jaringan komputer dan telekomunikasi di era revolusi industri ini menjadi kunci utama untuk kepentingan analisis yang lebih luas. Pengujian dan analisis tingkat keamanan pada embedded system over VoIP Intertet of Things menjadi tantangan pekerjaan penelitian yang menarik untuk dikerjakan selanjutnya.

\section{UCAPAN TERIMA KASIH}

Penulis mengucapkan terima kasih kepada Jurusan Teknik Elektro atas dukungan dan fasilitas Laboratorium Elektronika dan Jaringan Komputer yang disediakan guna terlaksananya pekerjaan ini. Kepada Fakultas Teknik, Universitas Muhammadiyah Malang, atas dukungan melalui skema program Penelitian dan Pengabdian Fakultas PUSKAREKA, terima kasih dan apresiasi diberikan yang setinggi-tingginya.

\section{DAFTAR PUSTAKA}

[1] L. S. Tanutama, R. A. Poernama, Yansen, and W. Riani, "Performansi Komunikasi VoIP - SIP Dengan GSM Melalui GSM Gateway," J. Tek. Komput., vol. 18, no. 2, pp. 100$108,2008$.

[2] Y. Patih, D. F. J., Fitriawan, H., \& Yuniati, “Analisa Perancangan Server Voip (Voice Internet Protocol) Dengan Opensource Asterisk Dan VPN (Virtual Private Network) Sebagai Pengaman Jaringan Antar Client," J. Inform. Dan Tek. Elektro Terap., vol. 1, no. 1, pp. 42-48, 2012.

[3] E. B. Setiawan, "Analisa Quality Of Services (QoS) Voice Over Internet Protocol (VoIP) Dengan Protokol H.323 Dan Session Initial Protocol (SIP)," J. Ilm. Komput. Dan Inform., vol. 1, no. 2, pp. 1-8, 2012.

[4] M. I. Wahyuddin, "Implementasi Voip Computer To Computer Berbasis Freeware Menggunakan Session Initiation Protocol," J. Artif. ICT Res. Cent., vol. 3, no. 1, pp. 5059, 2009.

[5] N. Yuliana, M., Kristalina, P., \& Munif, "Analisa dan Implementasi VoIP SIP pada Mobile Phone di Jaringan Bluetooth,” EEPIS J., pp. 73-81, 2010.

[6] B. Prasetyo, "Analisis Implementasi Voice Over Internet Protocol (VoIP) Pada Jaringan Wireless LAN Berbasis Session Initiation Protocol (SIP)," Telkom University, 2006.

[7] Ç. Yıldız, B. Kurt, T. Y. Ceritli, B. Sankur, and A. T. Cemgil, "A real-time SIP network simulation and monitoring system," SoftwareX, vol. 8, pp. 21-25, 2018.

[8] E. Mufida, D. Irawan, and G. Chrisnawati, "Remote Site Mikrotik VPN Dengan Point To Point Tunneling Protocol (PPTP) Studi Kasus Pada Yayasan Teratai Global Jakarta," J. MATRIK, vol. 16, no. 2, pp. 9-19, 2017.

[9] W. Bin Hsieh and J. S. Leu, "Implementing a secure VoIP communication over SIPbased networks," Wirel. Networks, vol. 24, no. 8, pp. 2915-2926, 2018.

[10] M. I. Haji, S. Purwantoro, and S. P. Arifin, "Analysis Tunneling IPv4 and IPv6 on VoIP Network," Kinet. Game Technol. Inf. Syst. Comput. Network, Comput. Electron. Control, vol. 3, no. 4, pp. 337-344, 2018.

[11] I. W. E. P. Darmawan, "Rancang Bangun Keamanan Transfer Data Voip Over Vpn Pada Sistem Opensource Trixbox," J. Pendidik. Teknol. dan Kejuru., vol. 11, no. 1, pp. 1-12, 
2014.

[12] P. K. Dhillon and S. Kalra, "Secure and efficient ECC based SIP authentication scheme for VoIP communications in internet of things," Multimed. Tools Appl., pp. 2219922222, 2019.

[13] D. A. Wijaksono, "Pembuatan Jaringan PABX Dengan Sistem VoIP Menggunakan Sistem Operasi Linux Trixbox," Universitas Muhammadiyah Surakarta, 2012.

[14] F. Z. Nasihin, A. B. P. Negara, and A. Irwansyah, "Studi Perbandingan Performa QoS (Quality of Service) Tunneling Protocol PPTP Dan L2TP Pada Jaringan VPN Menggunakan Mikrotik," J. Sist. dan Teknol. Inf., vol. 4, no. 1, pp. 1-6, 2016. 